\title{
REVIEW
}

\section{Clinical review: Prothrombin complex concentrates - evaluation of safety and thrombogenicity}

\author{
Benny Sørensen ${ }^{1 *}$, Donat R Spahn², Petra Innerhofer ${ }^{3}$, Michael Spannag ${ }^{4}$ and Rolf Rossaint ${ }^{5}$
}

\begin{abstract}
Prothrombin complex concentrates (PCCs) are used mainly for emergency reversal of vitamin K antagonist therapy. Historically, the major drawback with PCCs has been the risk of thrombotic complications. The aims of the present review are to examine thrombotic complications reported with PCCs, and to compare the safety of PCCs with human fresh frozen plasma. The risk of thrombotic complications may be increased by underlying disease, high or frequent PCC dosing, and poorly balanced PCC constituents. The causes of PCC thrombogenicity remain uncertain but accumulating evidence indicates the importance of factor II (prothrombin). With the inclusion of coagulation inhibitors and other manufacturing improvements, today's PCCs may be considered safer than earlier products. PCCs may be considered preferable to fresh frozen plasma for emergency anticoagulant reversal, and this is reflected in the latest British and American guidelines. Care should be taken to avoid excessive substitution with prothrombin, however, and accurate monitoring of patients' coagulation status may allow thrombotic risk to be reduced. The risk of a thrombotic complication due to treatment with PCCs should be weighed against the need for rapid and effective correction of coagulopathy.
\end{abstract}

\section{Introduction}

Prothrombin complex concentrates (PCCs) were originally developed as a source of factor IX for the treatment of patients with haemophilia B [1]. Subsequently, PCCs were used in the treatment of bleeding in haemophilia

${ }^{*}$ Correspondence: benny.sorensen@kcl.ac.uk

'Haemostasis Research Unit, Centre for Haemostasis and Thrombosis, Department of Haematology and Oncology, Guy's and St Thomas' Hospital \& NHS Trust Foundation, King's College London School of Medicine, 1st Floor, North Wing, St Thomas' Hospital, Westminster Bridge Road, London SE1 7EH, UK

Full list of author information is available at the end of the article patients with inhibitors [1]. These concentrates have largely been superseded in this setting by high-purity, plasma-derived factor IX and, more recently, recombinant factor IX and bypassing agents such as activated PCC and recombinant activated factor VII.

Today, PCCs are mainly used for the emergency reversal of oral vitamin K antagonist (VKA) therapy [2,3], although in the USA they are only approved for haemophilia. Bleeding is the most frequent complication of oral anticoagulation, causing considerable morbidity and mortality [4]. Emergency reversal of anticoagulation is most commonly needed to control bleeding as quickly as possible. The use of PCCs has also been proposed in severe liver disease and in perioperative and traumarelated bleeding [5-8], although fewer studies have been performed in these settings than for anticoagulation reversal.

Most commercially available PCCs contain four vitamin K-dependent coagulation factors (II, VII, IX and $\mathrm{X}$ ), although not all contain factor VII (Table 1). A recent study of PCC constituents found broad correlation with the products' labelled values [9]. In most currently available PCCs, the factors are found in the inactivated form. In addition to the coagulation factors, many of today's PCCs include one or more of the following coagulation inhibitors: heparin, antithrombin, protein $\mathrm{C}$, protein $\mathrm{S}$ and protein $\mathrm{Z}$.

In settings where rapid correction of coagulopathy is required, such as in cases of intracranial haemorrhage [10], PCCs may offer some advantages over fresh frozen plasma (FFP), the traditionally established therapy. For reasons such as reduced volume, room-temperature storage and lack of requirement for blood type matching, the total time for administration is much reduced with PCCs compared with FFP. Furthermore, most currently available PCCs are subjected to at least one viral inactivation step (Table 1), which reduces the risk of pathogen transmission. Also, as PCCs are free of leukocytes and some are also nanofiltrated, they are unlikely to provoke transfusion-related acute lung injury.

Historically, the major drawback of PCCs has been the risk of thrombotic complications [11]. Today's PCCs differ considerably from the preparations used to treat 
Table 1. Composition of PCCs in the World Federation of Hemophilia register of clotting factor concentrates

\begin{tabular}{|c|c|c|c|c|c|c|c|}
\hline \multirow[b]{2}{*}{ Brand name } & \multirow[b]{2}{*}{ Manufacturer } & \multicolumn{4}{|c|}{ International units relative to factor IX } & \multirow[b]{2}{*}{ Viral inactivation } & \multirow[b]{2}{*}{$\begin{array}{l}\text { Additional } \\
\text { information }\end{array}$} \\
\hline & & $\begin{array}{c}\text { Factor } \\
\text { II }\end{array}$ & $\begin{array}{l}\text { Factor } \\
\text { VII }\end{array}$ & $\begin{array}{l}\text { Factor } \\
\text { IX }\end{array}$ & $\begin{array}{l}\text { Factor } \\
\quad \mathrm{X}\end{array}$ & & \\
\hline Bebulin VH & $\begin{array}{l}\text { Baxter BioScience, } \\
\text { Austria }\end{array}$ & 120 & (13) & 100 & 100 & $\begin{array}{l}\text { Vapour heat, } 60^{\circ} \mathrm{C} \text { for } 10 \text { hours at } 190 \mathrm{mbar} \text {, } \\
\text { then } 80^{\circ} \mathrm{C} \text { for } 1 \text { hour at } 375 \mathrm{mbar}\end{array}$ & Heparin added \\
\hline Beriplex P/N & $\begin{array}{l}\text { CSL Behring, } \\
\text { Germany }\end{array}$ & 128 & 68 & 100 & 152 & $\begin{array}{l}\text { Pasteurisation at } 60^{\circ} \mathrm{C} \text { for } 10 \text { hours, and } \\
\text { nanofiltration }\end{array}$ & $\begin{array}{l}\text { Protein } C_{i} \\
\text { antithrombin, heparin } \\
\text { and albumin added }\end{array}$ \\
\hline Cofact & $\begin{array}{l}\text { Sanquin, } \\
\text { the Netherlands }\end{array}$ & $56-140$ & $28-80$ & 100 & $56-140$ & $\begin{array}{l}\text { Solvent/detergent and } 15 \mathrm{~nm} \\
\text { nanofiltration }\end{array}$ & Antithrombin added \\
\hline KASKADIL & LFB, France & 148 & 40 & 100 & 160 & Solvent/detergent & Heparin added \\
\hline Octaplex & $\begin{array}{l}\text { Octapharma, Austria } \\
\text { and France }\end{array}$ & $44-152$ & $36-96$ & 100 & 50 & Solvent/detergent and nanofiltration & $\begin{array}{l}\text { Heparin added; low } \\
\text { activated factor VII } \\
\text { content }\end{array}$ \\
\hline Profilnine SD & Grifols, USA & 148 & (11) & 100 & 64 & Solvent/detergent & - \\
\hline Prothrombinex VF & $\begin{array}{l}\text { CSL Bioplasma, } \\
\text { Australia }\end{array}$ & 100 & $(-)$ & 100 & 100 & $\begin{array}{l}\text { Dry heat, } 80^{\circ} \mathrm{C} \text { for } 72 \text { hours and } \\
\text { nanofiltration }\end{array}$ & - \\
\hline Prothromplex T & $\begin{array}{l}\text { Baxter BioScience, } \\
\text { Austria }\end{array}$ & 100 & 85 & 100 & 100 & $\begin{array}{l}\text { Vapour heat, } 60^{\circ} \mathrm{C} \text { for } 10 \text { hours at } 190 \mathrm{mbar} \text {, } \\
\text { then } 80^{\circ} \mathrm{C} \text { for } 1 \text { hour at } 375 \mathrm{mbar}\end{array}$ & $\begin{array}{l}\text { Antithrombin and } \\
\text { heparin added }\end{array}$ \\
\hline UMAN Complex D.I. & Kedrion, Italy & 100 & $(-)$ & 100 & 80 & $\begin{array}{l}\text { Solvent/detergent and dry heat, } 100^{\circ} \mathrm{C} \text { for } \\
30 \text { minutes }\end{array}$ & $\begin{array}{l}\text { Antithrombin and } \\
\text { heparin added }\end{array}$ \\
\hline
\end{tabular}

Composition of prothrombin complex concentrates (PCCs) listed in the World Federation of Hemophilia register of clotting factor concentrates [54], excluding concentrates for national markets only or for which the concentrations of factors relative to factor IX were not available from the relevant product information sheets. Factor VII presented in parentheses for three-factor PCCs.

haemophiliacs in the 1970s and 1980s, and in general the risk of thrombosis with PCCs appears to have been reduced. Nevertheless, accurate risk-benefit assessments of PCC therapy are dependent on thorough understanding of the potential for thrombogenicity. The aims of the present review are to provide a systematic overview of thrombotic complications reported with PCCs, to examine the possible pathogenesis of thrombotic events, and to discuss safety precautions and means to reduce thrombotic complications. Furthermore, the review performs a critical comparison of PCC with FFP.

\section{Literature search strategy}

We used the PUBMED database to search for publications with 'complex concentrate(s)' or 'coagulation factor concentrate(s)' as key words, plus additional terms including 'anticoagulation reversal' and 'over-anticoagulation. Citations were selected from articles published in English between 1988 and 2010.

\section{Thrombotic complications with PCCs}

Thrombotic complications associated with PCCs include venous thromboembolism, disseminated intravascular coagulation (DIC), microvascular thrombosis and myocardial infarction [1]. An overview of studies that have reported such complications is presented in Table 2. The risk of thrombotic complications occurring with PCCs or other procoagulant haemostatic interventions must be considered in the context of any underlying disease and the patient's clinical condition at the time of PCC administration [12].

\section{Haemophilia}

Prior to the introduction of high-purity, plasma-derived factor IX, haemophilia B patients were treated with PCCs. As haemophilia B patients are deficient in factor IX only, administration of PCC will produce supraphysiological levels of the other factors in the preparation this, coupled with the need for repetitive dosing in haemophilia B, can increase patients' risk of thrombosis. Since the introduction of PCCs for haemophilia in the 1960s, complications such as deep vein thrombosis, DIC and pulmonary embolism have been reported. In a survey of 150 physicians in several countries, 72 thrombotic complications occurring between 1987 and 1990 were reported [11]. An increased risk of adverse effects was seen in patients with large muscle haematomas, immobilisation and orthopaedic surgery. In these conditions, treatment involves administration of large, repeated doses of PCCs [11]. In the 1980s, several cases of acute myocardial infarction in young haemophiliacs with inhibitors were reported; many of these patients had received large, repeated doses of PCCs [13].

\section{Anticoagulation reversal}

All patients receiving VKA therapy have underlying thrombotic risk factors, which may be unmasked when anticoagulation is reversed. A review of 14 studies each 
Table 2. Studies reporting thrombogenic complications associated with the use of PCCs

\begin{tabular}{|c|c|c|c|c|c|c|}
\hline Publication & Study type & $\begin{array}{l}\text { PCC } \\
\text { indication }\end{array}$ & $\begin{array}{l}\text { Number of } \\
\text { patients }\end{array}$ & $\begin{array}{l}\text { Number of } \\
\text { thrombotic } \\
\text { complications }\end{array}$ & Nature of complications & Notes \\
\hline Lusher [11] & $\begin{array}{l}\text { Physician survey } \\
\text { and registry }\end{array}$ & Haemophilia & $\begin{array}{l}\text { Not available } \\
\text { (150 physicians } \\
\text { surveyed) }\end{array}$ & $\begin{array}{l}72 \text { (reported } \\
\text { over a } \\
4 \text {-year period) }\end{array}$ & $\begin{array}{l}\text { Various (for example, deep } \\
\text { venous thrombosis of the } \\
\text { leg, pulmonary embolus, DIC) }\end{array}$ & $\begin{array}{l}\text { Increased risk among patients } \\
\text { receiving large, repeated } \\
\text { doses of PCC }\end{array}$ \\
\hline $\begin{array}{l}\text { Lankiewicz and } \\
\text { colleagues [15] }\end{array}$ & $\begin{array}{l}\text { Retrospective } \\
\text { review }\end{array}$ & Warfarin reversal & 58 & 4 & $\begin{array}{l}\text { Deep vein thrombosis }(n=2) \text {, } \\
\text { non-ST elevation myocardial } \\
\text { infarction }(n=2)\end{array}$ & $\begin{array}{l}\text { Thrombotic complications } \\
\text { were not attributable to PCC } \\
\text { therapy }\end{array}$ \\
\hline $\begin{array}{l}\text { van Aart and } \\
\text { colleagues [16] }\end{array}$ & $\begin{array}{l}\text { Prospective, } \\
\text { randomised } \\
\text { controlled trial }\end{array}$ & $\begin{array}{l}\text { Oral anticoagulation } \\
\text { reversal } \\
\text { (acenocoumarol or } \\
\text { phenprocoumon) }\end{array}$ & 93 & 2 & Thrombotic stroke $(n=2)$ & $\begin{array}{l}\text { Both patients were elderly and } \\
\text { had atrial fibrillation; one had } \\
\text { vascular disease and the other } \\
\text { had a large haematoma }\end{array}$ \\
\hline $\begin{array}{l}\text { Preston and } \\
\text { colleagues [17] }\end{array}$ & $\begin{array}{l}\text { Prospective, } \\
\text { uncontrolled } \\
\text { trial }\end{array}$ & Warfarin reversal & 42 & 1 & Thrombotic stroke & $\begin{array}{l}\text { Stroke occurred following leg } \\
\text { amputation, } 48 \text { hours after } \\
\text { PCC treatment. Patient had } \\
\text { peripheral vascular disease }\end{array}$ \\
\hline $\begin{array}{l}\text { Pabinger- } \\
\text { Fasching and } \\
\text { colleagues } \\
{[18,55]}\end{array}$ & $\begin{array}{l}\text { Prospective, } \\
\text { uncontrolled } \\
\text { trial }\end{array}$ & $\begin{array}{l}\text { Oral anticoagulation } \\
\text { reversal (vitamin K } \\
\text { antagonists) }\end{array}$ & 43 & 1 & $\begin{array}{l}\text { Suspected pulmonary } \\
\text { embolism (fatal) }\end{array}$ & $\begin{array}{l}\text { Patient had risk of thrombosis } \\
\text { due to metastatic } \\
\text { gastrointestinal cancer and } \\
\text { atrial fibrillation }\end{array}$ \\
\hline $\begin{array}{l}\text { Bagot and } \\
\text { colleagues [19] }\end{array}$ & Case report & Warfarin reversal & 1 & 1 & Myocardial infarction (fatal) & $\begin{array}{l}\text { No definite causal link with } \\
\text { PCC administration; patient } \\
\text { may have had DIC related to } \\
\text { abdominal sepsis }\end{array}$ \\
\hline $\begin{array}{l}\text { Warren and } \\
\text { Simon [20] }\end{array}$ & Case report & Warfarin reversal & 1 & 1 & Intracardial thrombosis (fatal) & $\begin{array}{l}\text { Patient had a history of } \\
\text { ischaemic stroke and deep } \\
\text { venous thrombosis; general } \\
\text { disturbance of coagulation }\end{array}$ \\
\hline $\begin{array}{l}\text { Kohler and } \\
\text { colleagues [22] }\end{array}$ & $\begin{array}{l}\text { Case reports } \\
(n=5)\end{array}$ & $\begin{array}{l}\text { Perioperative setting, } \\
\text { acquired deficiencies } \\
\text { of coagulation factors }\end{array}$ & s & 5 & Thrombotic events (fatal) & $\begin{array}{l}\text { All patients received an old } \\
\text { PCC that was withdrawn in } \\
\text { 1994; all patients had } \\
\text { underlying diseases } \\
\text { predisposing them to } \\
\text { thrombosis or DIC }\end{array}$ \\
\hline
\end{tabular}

DIC, disseminated intravascular coagulation; PCC, prothrombin complex concentrate.

involving at least 10 patients (a total of 460 patients) in which PCCs were administered for anticoagulation reversal revealed no evidence of DIC [14]. There were, however, seven thrombotic complications (that is, $1.5 \%$ of patients experienced a thrombotic event). Four of these, two deep vein thromboses and two non-ST elevation myocardial infarctions which were identified in a retrospective review of 58 patients, were not attributed to PCC therapy [15]. Two thrombotic strokes occurred in patients with extensive co-morbidities [16]. The first patient, a 75-year-old male, suffered from multi-infarct brain damage, longstanding hypertension, atrial fibrillation and vascular disease of the legs. The other patient was an 86-year-old female with atrial fibrillation and a large haematoma in the left leg. Finally, a patient with peripheral vascular disease, sepsis and renal and cardiac failure died of a thrombotic stroke 48 hours after PCC treatment, following leg amputation [17].

Three further thrombotic complications associated with PCC use have been identified in articles published since Leissinger and colleagues' review [14]. A study of
PCC use in 43 patients requiring emergency reversal of VKA therapy was published more recently [18]. One serious adverse event, suspected pulmonary embolism leading to the death of a patient, was considered possibly related to study treatment. This patient had an underlying risk of thrombosis relating to metastatic gastrointestinal cancer and atrial fibrillation. In a recent case report, a patient receiving PCC for anticoagulant reversal suffered a fatal myocardial infarction [19]. Myocardial infarction is a frequent perioperative complication in the absence of PCC treatment and no definite causal link with PCC administration could be established in this case. Furthermore, the patient may have had DIC related to abdominal sepsis. A second case report, published by Warren and Simon, involved a patient who received treatment with PCC and subsequently suffered massive, fatal intracardial thrombosis [20]. Although the authors suggest this may have been a complication of PCC treatment, there were several important underlying risk factors. The patient had a history of ischaemic stroke and deep venous thrombosis. The International Normalised 
Ratio was extremely high (12.8) and the partial thromboplastin time was elongated, suggesting very low levels of prothrombin, factor VII and protein C; levels of liver enzymes were also high. These factors indicate general disturbance of coagulation independent of PCC administration. Furthermore, serum potassium was at a level high enough to potentially cause cardiac arrest, and the patient's creatinine level $(5.2 \mathrm{mg} / \mathrm{dl})$ indicates renal failure.

In all of these cases, therefore, the patients receiving PCCs had increased risk of thrombosis due to medical history or current illness. As this reflects the usual context of PCC administration, a small number of complications may be expected. The possibility that PCC administration has some influence over the risk cannot be excluded. In most recent cases in the literature, however, it seems unlikely that PCC alone was the cause.

\section{Perioperative and trauma-related bleeding}

During the past decade, there have been several reports of PCC therapy for critical bleeding. The aim of this approach is to correct critically reduced thrombin generation, resulting from major blood loss, consumption of coagulation factors and volume administration (this excludes patients requiring anticoagulation reversal or with a procoagulant status and prophylactic use of PCCs). Although there have been few authoritative studies of PCCs in this setting, the clinical practice has been used in European countries such as Austria, Germany and Switzerland in cases with increased bleeding and prolonged initiation of coagulation as measured by viscoelastic techniques [21]. Recently published Austrian expert opinion consensus recommendations advocate administration of PCC (20 to $30 \mathrm{IU} / \mathrm{kg}$ bodyweight) in the case of persistent bleeding and prolonged clotting time [6]. Adequate substitution of fibrinogen was also recommended, prior to administration of PCC.

Regarding the possible complications associated with accelerating thrombin generation by administration of PCC in the perioperative setting, a cluster of five fatal PCC-related thrombotic events in German patients undergoing surgery was reported in the 1990s [22]. None of these cases may be considered classical perioperative PCC use: two patients required anticoagulation reversal, two patients had procoagulant states (including sepsis, DIC or high levels of platelets and fibrinogen), and one patient received PCC prophylactically (that is, without clinical signs of bleeding). All five patients were treated with an old PCC that was withdrawn from the market in 1994 as a result of three of the fatalities [22]. Compared with other PCCs available at the time, the withdrawn product had high levels of factors II and X and activated factor VII, low levels of protein S, and no free antithrombin activity, although heparin levels were relatively high $[22,23]$. Co-administration of aprotinin was also identified as playing a possible role in three of the cases [22]. More recently, there have been no reports of thrombotic complications with PCCs in the treatment of perioperative or trauma-related bleeding, although only a few studies have been published in these settings $[8,24,25]$.

\section{PCCs and thrombotic risk: pathogenesis}

The potential causes of thrombogenic complications after PCC administration remain a subject for debate. Early studies in animal models implicated activated factor IX or the presence of procoagulant phospholipids as potential thrombogenic determinants in PCCs [26,27]. A reduction in thromboembolic complications among haemophilia B patients was observed when highly-purified factor IX began to replace PCCs. However, direct measurement of activated factor IX revealed that there tended to be higher levels in highly-purified factor IX preparations than in PCCs [28], suggesting that levels of activated factor IX do not correlate with thrombogenicity.

An in vitro model of thrombogenicity has been used recently to systematically examine which components of PCCs contribute to thrombogenicity [29]. Zymogen overload, of prothrombin in particular, was implicated in this study as the main mechanism for the thrombogenic potential of PCCs. Other studies have also cited prothrombin as the major determinant of excessive thrombin generation in an activated PCC preparation [30].

The need for balance between procoagulants and anticoagulants was suggested by a recent in vitro study of thrombin generation in blood from patients with liver cirrhosis [31]. The authors suggest that haemostasis is preserved in these patients because the reduction of procoagulants (factor II) is balanced by reduced levels of the coagulation inhibitor protein $C$.

Two studies, using different methodologies, have shown that increased levels of factors VII, IX and X did not influence total thrombin generation $[32,33]$. In contrast, there is a linear relationship between increasing levels of factor II and increased thrombin generation $[32,33]$. Finally, a recently published study has shown that, following activation with a high concentration of tissue factor, prothrombin is amongst the main determinants of total thrombin generation [34]. The available evidence therefore indicates that accumulation of factor II could be the primary determinant of thrombotic risk associated with frequent doses of PCC. The half-lives of the coagulation factors differ considerably, with factors II and $\mathrm{X}$ having the longest half-lives of the factors administered in PCC (60 and 30 hours, respectively, compared with 6 hours for factor VII and 20 hours for factor IX) [35]. As a consequence, repeated dosing will lead to an accumulation of factors II and X as illustrated in Figure 1. 


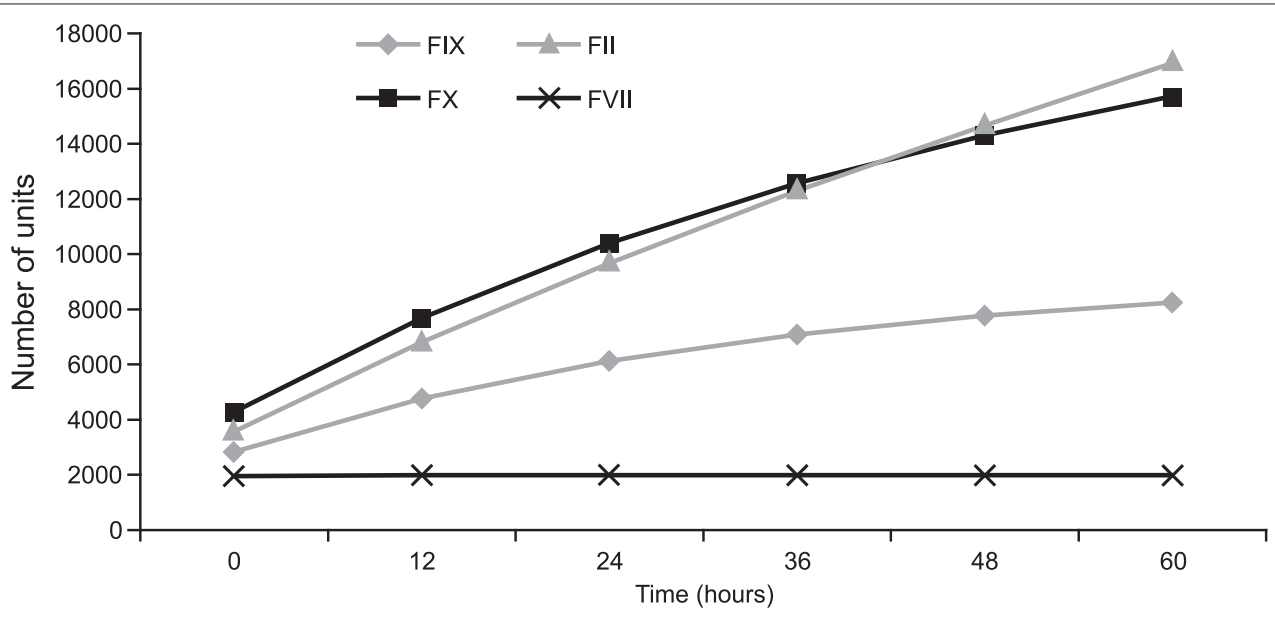

Figure 1. Coagulation factors accumulate differently when a prothrombin complex concentrate is administered repeatedly. Illustration of how coagulation factors accumulate differently when a prothrombin complex concentrate (PCC) is administered repeatedly due to their different half-lives. The example shows the theoretical accumulation of factors in plasma sampled immediately after dosing when 40 units/kg four-factor PCC is given every 12 hours to a $70 \mathrm{~kg}$ patient.

Overall, there remains some uncertainty as to which component(s) of PCCs is the leading cause of thrombogenicity, but there is accumulating evidence for the importance of factor II and the balance between this coagulation factor and coagulation inhibitors.

\section{Differences between today's PCCs and older products}

Today's PCCs have improved safety compared with those used in the 1970s and 1980s [12]. This improvement is probably related to the inclusion of coagulation inhibitors such as heparin, antithrombin, protein $C$, protein $S$ and protein Z. These constituents may be speculated to provide some balance to the effects of the coagulation factors, the aims being to avoid excessive increase in thrombin generation and to reduce thrombotic risk. The inclusion of coagulation inhibitors is consistent with recommendations to administer early PCCs together with heparin and antithrombin [11].

The effects of one currently available PCC (Beriplex P/N; CSL Behring, Marburg, Germany) have been studied in healthy volunteers $(n=15)$ [36]. Considerable increases in coagulation factor levels were observed, and these were accompanied by increases in plasma concentrations of proteins $\mathrm{C}$ and $\mathrm{S}$. Importantly, there was no clinical evidence of thrombosis, and no increase in the thrombogenicity marker D-dimer [36].

In a recent study, the biochemical composition of seven commercially available PCCs was measured. With one exception - Uman Complex (Kedrion, Castelvecchio Pascoli, Italy), which contained negligible factor VII coagulation factor levels were broadly similar in all seven products, and all tested negative for activated coagulation factors [9]. There were, however, some differences in coagulation inhibitor levels (Figure 2), resulting in different thrombin inhibitory capacities. There were also considerable purity differences between the products. It is noteworthy that all of the PCCs contained considerable concentrations of prothrombin (factor II), and that S-TIM 4 or Prothromplex (Baxter, Vienna, Austria) had a higher factor II:factor IX ratio than the other products [9].

Pharmacovigilance data for some of the currently available PCCs (Table 3) demonstrate that, although millions of units have been administered to thousands of patients, there have been no proven cases of infection transmission, heparin-induced thrombocytopaenia or thromboembolism.

One may question how the safety profile of today's three-factor PCCs compares with that of the four-factor products. Unfortunately no comparator trials have been performed, so there are no definitive answers. Given the apparent importance of factor II in thrombotic risk, and the fact that the key difference between the two types of PCC is the presence or absence of factor VII, no major inherent differences may be expected. Three-factor PCCs have been reported as suboptimal for warfarin reversal, owing to the absence of factor VII [37]. Thus. it has been recommended that four-factor PCCs are probably preferable to three-factor PCCs or FFP, for acute reversal of oral VKAs [38].

\section{Comparing PCCs with human plasma}

The primary alternative to PCCs - particularly for anticoagulant reversal, but also for treatment of acquired coagulopathy in the perioperative setting - is human plasma. Thrombotic complications with human plasma 


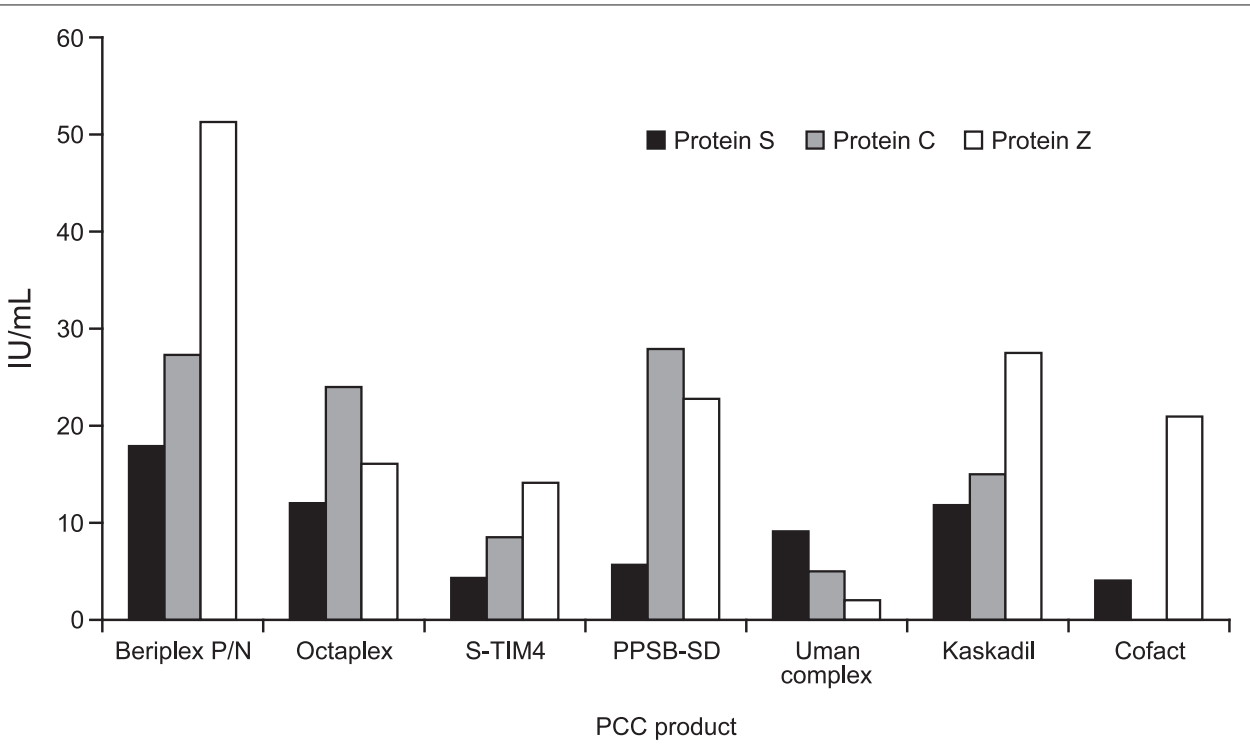

Figure 2. Coagulation inhibitor levels of different prothrombin complex concentrates. Protein C, protein S and protein Z contents of different prothrombin complex concentrates (PCCs) [9].

Table 3. Pharmacovigilance data for some of the commercially available PCCs

\begin{tabular}{|c|c|c|c|c|c|c|}
\hline $\begin{array}{l}\text { Brand name } \\
\text { (manufacturer) }\end{array}$ & $\begin{array}{l}\text { Dates of } \\
\text { survey }\end{array}$ & $\begin{array}{l}\text { Amount } \\
\text { produced } \\
\text { to date }\end{array}$ & $\begin{array}{l}\text { Estimated } \\
\text { number of } \\
\text { applications }\end{array}$ & $\begin{array}{l}\text { Number of } \\
\text { cases of } \\
\text { proven infection } \\
\text { transmission }\end{array}$ & $\begin{array}{l}\text { Number of } \\
\text { cases of } \\
\text { HIT type II }\end{array}$ & $\begin{array}{c}\text { Number of } \\
\text { cases of } \\
\text { proven } \\
\text { thromboembolism }\end{array}$ \\
\hline $\begin{array}{l}\text { Beriplex P/N } \\
\text { (CSL Behring, } \\
\text { Germany) }\end{array}$ & 1996 to 2004 & $\begin{array}{c}>400 \text { million } \\
\text { units }\end{array}$ & $\begin{array}{l}>200,000 \\
\text { (average dose } \\
2,000 \text { units) }\end{array}$ & 0 & 0 & $\begin{array}{c}0 \text { (two cases were reported } \\
\text { but PCC not established as } \\
\text { the cause) }\end{array}$ \\
\hline $\begin{array}{l}\text { Cofact } \\
\text { (Sanquin, } \\
\text { The Netherlands) }\end{array}$ & 1997 to 2006 & $\begin{array}{l}\sim 97 \text { million } \\
\text { units }\end{array}$ & $\begin{array}{l}\text { 64,000 to } 82,500 \\
\text { (average dose } \\
20 \text { to } 50 \mathrm{ml} \text { ) }\end{array}$ & 0 & 0 & 0 \\
\hline $\begin{array}{l}\text { Uman } \\
\text { Complex D.I. } \\
\text { (Kedrion, Italy) }\end{array}$ & 2005 to 2007 & $\begin{array}{c}\sim 31.5 \text { million } \\
\text { units }\end{array}$ & $\begin{array}{l}\sim 16,000 \\
\text { (average dose } \\
2,000 \text { units) }\end{array}$ & 0 & 0 & 0 \\
\hline
\end{tabular}

Pharmacovigilance data for some of the commercially available prothrombin complex concentrates (PCCs) listed in the World Federation of Hemophilia register of clotting factor concentrates, excluding those for national markets only [54]. HIT, heparin-induced thrombocytopaenia.

are rare, which could be cited as an advantage versus PCCs. However, there are major drawbacks with human plasma versus PCCs. Firstly, a considerably longer time is taken to reach haemostasis with human plasma. Before it can be administered, compatibility testing is required and the human plasma must be thawed and warmed. The low concentration of coagulation factors in normal human plasma means that a large volume may be required to deliver enough of the factors to achieve effective haemostasis. As well as the risk of volume overload, this results in an extended administration time. Hence, the time taken for preparation and administration of human plasma is typically 1 or 2 hours. In contrast, PCCs can be administered immediately and a lower volume is required; an important consideration when the rapid reversal of anticoagulant therapy may be life-saving.
Human plasma transfusion is associated with other potential adverse reactions, including transfusion-related acute lung injury and allergic reaction [39]. FFP is also associated with a risk of allergic reactions, such as skin rash, pruritus, urticaria, bronchospasm, angioedema and anaphylactic shock [40]. Studies have shown that infusion of FFP is associated with increased risk and frequency of hospital-acquired infections [41], and that there is a small potential risk of disease transmission with human plasma [5]. In contrast, PCC manufacture includes at least one step of viral reduction or elimination, which minimises the risk of transmitting infectious agents.

It is discouraging, faced with the potential side-effects of FFP, that available data on the efficacy of FFP are scarce $[42,43]$. Several studies comparing the efficacy of PCCs with human plasma for emergency oral anticoagulant 
reversal have shown that PCCs provide more effective and more rapid correction of coagulopathy [44-47]. These findings, together with the improved safety profile of today's PCCs, suggest that PCCs should be considered preferable to FFP for emergency oral anticoagulant reversal. This is reflected in the latest British and American guidelines on the reversal of anticoagulation as well as other review articles $[2,3,14,38]$.

\section{Possible means of reducing thrombotic risk}

As PCCs were originally designed for the treatment of haemophilia B, their labelling, and thus dosage, is based on the concentration of factor IX. When PCCs are used for VKA reversal, it is important to recognise that warfarin reduces the levels of the vitamin K-dependent coagulation factors to varying degrees, with factor IX remaining at 40 to $50 \%$ of normal levels, factor VII at around $30 \%$ of normal, prothrombin at $20 \%$ of normal and factor $\mathrm{X}$ is usually lowest at around $10 \%$ of normal [48]. As a result, it is difficult to define the optimal ratio of factors in a PCC. Care should be taken, however, to avoid excessive substitution with prothrombin, particularly during repetitive administration of PCCs when prothrombin levels can accumulate because of its long half-life. Co-administration of vitamin $\mathrm{K}$ is recommended when PCCs are used for anticoagulation reversal [2]. Vitamin $\mathrm{K}$ has a slow onset of action, and the reason for its use is to facilitate hepatic production of coagulation factors after the constituents of the PCC infusion have been metabolised. By reducing the need for repeat administration of PCC, co-administration of vitamin $\mathrm{K}$ is one way of reducing thrombotic risk.

Although the primary purpose of PCCs is the restoration of coagulation factors, it is also important to consider levels of coagulation inhibitors. VKA therapy reduces levels of protein $\mathrm{C}$, protein $\mathrm{S}$ and protein $\mathrm{Z}$ as well as the coagulation factors, and the concentration of circulating coagulation inhibitors will be reduced in dilutional coagulopathy. Furthermore, chronic liver disease - which was identified as a risk factor for thrombotic complications in haemophilia patients treated with earlier formulations of PCCs [12] - frequently causes a reduction in the production of antithrombin as well as coagulation factors [49]. To avoid thrombotic complications, monitoring of antithrombin activity and coadministration of antithrombin concentrate should be considered when administering PCCs to patients with severe liver disease [5]. Patients with low levels of endogenous antithrombin are likely to be at increased risk of thrombosis. There is, therefore, a strong rationale for the inclusion of coagulation inhibitors such as protein $\mathrm{C}$, protein $\mathrm{S}$ and protein $\mathrm{Z}$ or antithrombin in PCCs [50].

Accurate bedside monitoring of a patient's coagulation status may provide a means for reducing thrombotic risk.
Conventional coagulation tests such as the prothrombin time are not affected by levels of coagulation inhibitors such as protein C; the International Normalised Ratio may therefore not be a true reflection of the haemostatic state of a patient [31]. During volume replacement of blood loss, particularly with colloids, conventional prothrombin time and activated partial thromboplastin time assays may suggest critical reduction in coagulation factors, whereas the coagulation time measured in whole blood using thromboelastography may remain within the normal range [51]. Theoretically, thrombin generation measurement should be preferable for guiding PCC administration and monitoring its efficacy. This analysis is not yet routine in all laboratories, but thromboelastography provides a surrogate estimate of thrombin generation in whole blood $[52,53]$.

Ultimately, it is incumbent upon physicians to seek sufficient restoration of thrombin generation to achieve haemostasis. Normalisation may not be needed and may unmask an underlying predisposition of thromboembolism. An excessive increase in thrombin generation should thus be avoided. Caution must be exercised, and PCCs are generally not recommended for use in patients at very high risk of thrombosis, such as those with clinical or laboratory evidence of overt DIC.

\section{Conclusions}

The paradox remains that PCCs are effective because they increase the body's ability to generate thrombin, while the total thrombin generation constitutes the primary safety concern with their use. The overall capacity to produce thrombin seems to be primarily associated with prothrombin levels. The use of PCCs in patients predisposed to thrombogenic complications makes it difficult to determine whether thrombogenic events are attributable to or merely coincidental with PCC treatment. Thrombotic risk in patients without underlying risk appears to be fairly low with today's PCCs. Changes to the production of PCCs, designed to address the possible causes of thrombogenic complications, have contributed to their improved safety. These changes include the avoidance of activated factors, greater purity and a well-balanced content of clotting factors and inhibitors. However, additional factors that may contribute to thrombotic complications associated with PCC use remain to be elucidated. The putative benefit of combined administration of PCCs with antithrombin in high-risk patients such as those with liver insufficiency or on VKA therapy is as yet unconfirmed.

In patients with emergency bleeding, the risk of a thrombotic complication due to treatment with PCCs should be weighed against the need for rapid and effective correction of coagulopathy. 


\section{Abbreviations}

DIC, disseminated intravascular coagulation; FFP, fresh frozen plasma; PCC, prothrombin complex concentrate; VKA, vitamin K antagonist.

\section{Competing interests}

Benny Sørensen has participated in advisory boards and/or received speaker honorariums from Novo Nordisk, Baxter, CSL Behring, Bayer, Pentapharm and Biovitrum. The Haemostasis Research Unit receives unrestricted research support from Novo Nordisk, Grifols, CSL Behring, LFB, Baxter, Bayer and Octapharma.

Donat Spahn's academic department has received grant support from the University of Zurich, Zurich, Switzerland, the Research Award Center for Zurich Integrative Human Physiology, Zurich, Switzerland (no grant numbers are attributed), the Swiss National Science Foundation, Berne, Switzerland (grant number: SPUM 33CM30_124117), the European Society of Anaesthesiology (ESA), Brussels, Belgium (no grant numbers are attributed), the Swiss Society of Anesthesiology and Reanimation (SGAR), Berne, Switzerland (no grant numbers are attributed), the Swiss Foundation for Anesthesia Research, Zurich, Switzerland (no grant numbers are attributed), the Swiss Life Foundation Switzerland, Zurich, Switzerland (no grant numbers are attributed), Bundesprogramm Chancengleichheit, Berne, Switzerland (no grant numbers are attributed), Stiftung für Staublungen-Forschung, Zurich, Switzerland (no grant numbers are attributed), B. Braun, Sempach, Switzerland (no grant numbers are attributed), CSL Behring, Berne, Switzerland (no grant numbers are attributed), Vifor SA, Villars-sur-Glâne, Switzerland (no grant numbers are attributed) and UBS, Zurich, Switzerland (no grant numbers are attributed). Dr. Spahn is the chairman of the ABC Faculty and a member of the ABC Trauma Faculty which both are managed by Thomson Physicians World $\mathrm{GmbH}$, Mannheim, Germany and sponsored by an unrestricted educational grant from Novo Nordisk A/S, Bagsvärd, Denmark.

In the past 5 years, Dr. Spahn has received honoraria or travel support for consulting or lecturing from the following companies: Abbott AG, Baar Switzerland, AstraZeneca AG, Zug, Switzerland, Bayer (Schweiz) AG, Zürich, Switzerland, Baxter S.p.A., Roma, Italy, B. Braun Melsungen AG, Melsungen, Germany, Boehringer Ingelheim (Schweiz) GmbH, Basel, Switzerland, Bristol-Myers-Squibb, Rueil-Malmaison Cedex, France, CSL Behring GmbH, Hattersheim am Main, Germany and Bern, Switzerland, Curacyte AG, Munich, Germany, Ethicon Biosurgery, Sommerville, New Jersey, USA, Fresenius SE, Bad Homburg v.d.H., Germany, Galenica AG, Bern, Switzerland (including Vifor SA Villars-sur-Glâne, Switzerland), GlaxoSmithKline GmbH \& Co. KG, Hamburg, Germany, Janssen-Cilag AG, Baar, Switzerland, Novo Nordisk A/S, Bagsvärd, Denmark, Octapharma AG, Lachen, Switzerland, Organon AG, Pfäffikon/SZ, Switzerland, Oxygen Biotherapeutics, Costa Mesa, CA, Pentapharm GmbH (now tem Innovations $\mathrm{GmbH}$ ), Munich, Germany, Roche Pharma (Schweiz) AG, Reinach, Switzerland and Schering-Plough International, Inc., Kenilworth, New Jersey, USA.

In the past 5 years, Petra Innerhofer has received educational grants or honoraria for consulting or lecturing, costs incurring for travel and hotel accommodations and as partial support for conducting studies (without influence on study design, statistics and manuscript preparation) from the following companies: Baxter GmbH (Vienna, Austria), CSL Behring GmbH (Marburg, Germany), Novo Nordisk A/S (Bagsvaerd, Denmark), Octapharma AG (Vienna, Austria) and TEM innovations (formerly Pentapharm), (Munich, Germany).

Michael Spannagl has received lecturing fees from Baxter, Biotest, CSL Behring, NovoNordisk and Octapharma.

Rolf Rossaint has received lecturing and consulting fees from CSL Behring, Bayer HealthCare and NovoNordisk as well as financial support for animal studies from CSL Behring, NovoNordisk and Biotest.

\section{Acknowledgements}

Editorial assistance with the development of this manuscript was provided by Fishawack Communications Ltd. Financial support for this assistance was provided by CSL Behring $\mathrm{GmbH}$.

\section{Author details}

'Haemostasis Research Unit, Centre for Haemostasis and Thrombosis, Department of Haematology and Oncology, Guy's and St Thomas' Hospital \& NHS Trust Foundation, King's College London School of Medicine, 1st Floor, North Wing, St Thomas' Hospital, Westminster Bridge Road, London SE1 7EH, UK. ${ }^{2}$ Institute of Anesthesiology, University Hospital Zurich, CH-8091 Zurich,
Switzerland. ${ }^{3}$ Department of Anaesthesiology and Critical Care Medicine, Innsbruck Medical University, Anichstrasse 35, A-6020 Innsbruck, Austria. ${ }^{4}$ Working Group on Perioperative Hemostasis, Department of Anaesthesiology, University Hospital of Munich, Nussbaumstrasse 20, 80336 Munich, Germany. ${ }^{5}$ Department of Anaesthesiology, University Hospital Aachen, RWTH Aachen University, Pauwelsstrasse 30, 52074 Aachen, Germany.

Published: 12 January 2011

References

1. Key NS, Negrier C: Coagulation factor concentrates: past, present, and future. Lancet 2007, 370:439-448.

2. Ansell J, Hirsh J, Hylek E, Jacobson A, Crowther M, Palareti G: Pharmacology and management of the vitamin $\mathrm{K}$ antagonists: American College of Chest Physicians Evidence-Based Clinical Practice Guidelines (8th edition). Chest 2008, 133:160S-198S

3. Baglin TP, Keeling DM, Watson HG: Guidelines on oral anticoagulation (warfarin): third edition - 2005 update. Br J Haematol 2006, 132:277-285.

4. Palareti G, Leali N, Coccheri S, Poggi M, Manotti C, D'Angelo A, Pengo V, Erba N, Moia M, Ciavarella N, Devoto G, Berrettini M, Musolesi S: Bleeding complications of oral anticoagulant treatment: an inception-cohort, prospective collaborative study (ISCOAT). Italian Study on Complications of Oral Anticoagulant Therapy. Lancet 1996, 348:423-428.

5. Lorenz R, Kienast J, Otto U, Egger K, Kiehl M, Schreiter D, Kwasny H, Haertel S, Barthels M: Efficacy and safety of a prothrombin complex concentrate with two virus-inactivation steps in patients with severe liver damage. Eur J Gastroenterol Hepatol 2003, 15:15-20.

6. Coagulation Management in TraumaRelated Massive Bleeding [http://www.oegari.at/arbeitsgruppe.asp?id=116]

7. Spahn DR, Cerny V, Coats TJ, Duranteau J, Fernandez-Mondejar E, Gordini G, Stahel PF, Hunt BJ, Komadina R, Neugebauer E, Ozier Y, Riddez L, Schultz A, Vincent $J$, Rossaint R: Management of bleeding following major trauma: a European guideline. Crit Care 2007, 11:R17.

8. Staudinger T, Frass M, Rintelen C, Quehenberger P, Wagner O, Stoiser B, Locker GJ, Laczika K, Knapp S, Watzke H: Influence of prothrombin complex concentrates on plasma coagulation in critically ill patients. Intensive Care Med 1999, 25:1105-1110.

9. Kalina $U$, Bickhard $H$, Schulte S: Biochemical comparison of seven commercially available prothrombin complex concentrates. Int J Clin Pract 2008, 62:1614-1622

10. Imberti D, Barillari G, Biasioli C, Bianchi M, Contino L, Duce R, D'Inca M, Mameli L, Pinna L, Ageno W: Prothrombin complex concentrates for urgent anticoagulation reversal in patients with intracranial haemorrhage. Pathophysiol Haemost Thromb 2008, 36:259-265.

11. Lusher JM: Thrombogenicity associated with factor IX complex concentrates. Semin Hematol 1991, 28:3-5.

12. Kohler M: Thrombogenicity of prothrombin complex concentrates. Thromb Res 1999, 95:S13-S17

13. Lusher JM: Prediction and management of adverse events associated with the use of factor IX complex concentrates. Semin Hematol 1993, 30:36-40.

14. Leissinger CA, Blatt PM, Hoots WK, Ewenstein B: Role of prothrombin complex concentrates in reversing warfarin anticoagulation: a review of the literature. Am J Hematol 2007, 83:137-143.

15. Lankiewicz MW, Hays J, Friedman KD, Tinkoff G, Blatt PM: Urgent reversal of warfarin with prothrombin complex concentrate. J Thromb Haemost 2006, 4:967-970.

16. van Aart L, Eijkhout HW, Kamphuis JS, Dam M, Schattenkerk ME, Schouten TJ, Ploeger B, Strengers PF: Individualized dosing regimen for prothrombin complex concentrate more effective than standard treatment in the reversal of oral anticoagulant therapy: an open, prospective randomized controlled trial. Thromb Res 2006, 118:313-320.

17. Preston FE, Laidlaw ST, Sampson B, Kitchen S: Rapid reversal of oral anticoagulation with warfarin by a prothrombin complex concentrate (Beriplex): efficacy and safety in 42 patients. Br J Haematol 2002, 116:619-624.

18. Pabinger-Fasching I: Warfarin-reversal: results of a phase III study with pasteurised, nanofiltrated prothrombin complex concentrate. Thromb Res 2008, 122(Suppl 2):S19-S22.

19. Bagot CN, Cregg R, Patel RK, Shariff A, Arya R: Perioperative myocardial infarction in a patient receiving low-dose prothrombin complex concentrates. Thromb Haemost 2007, 98:1141-1142. 
20. Warren O, Simon B: Massive, fatal, intracardiac thrombosis associated with prothrombin complex concentrate. Ann Emerg Med 2009, 53:758-761.

21. Innerhofer P: Perioperative management of coagulation. Hamostaseologie 2006, 26:S3-S14.

22. Kohler M, Hellstern P, Lechler E, Uberfuhr P, Muller-Berghaus G: Thromboembolic complications associated with the use of prothrombin complex and factor IX concentrates. Thromb Haemost 1998, 80:399-402.

23. Hellstern P, Beeck H, Fellhauer A, Fischer A, Faller-Stockl B: Factor VII and activated-factor-VII content of prothrombin complex concentrates. The PCC Study Group. Vox Sang 1997, 73:155-161.

24. Bruce D, Nokes TJ: Prothrombin complex concentrate (Beriplex P/N) in severe bleeding: experience in a large tertiary hospital. Crit Care 2008, 12:R105.

25. Schick KS, Fertmann JM, Jauch KW, Hoffmann JN: Prothrombin complex concentrate in surgical patients: retrospective evaluation of vitamin $\mathrm{K}$ antagonist reversal and treatment of severe bleeding. Crit Care 2009, 13:R191.

26. Hultin MB: Activated clotting factors in factor IX concentrates. Blood 1979, 54:1028-1038.

27. Giles AR, Nesheim ME, Hoogendoorn H, Tracy PB, Mann KG: The coagulantactive phospholipid content is a major determinant of in vivo thrombogenicity of prothrombin complex (factor IX) concentrates in rabbits. Blood 1982, 59:401-407.

28. Kusch M, Seitz R, Konig H: High sensitivity detection of activated factor IX: application to the analysis of different therapeutical factor IX concentrates and prothrombin complexes. Thromb Haemost 1998, 79:778-783.

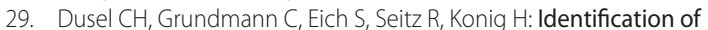
prothrombin as a major thrombogenic agent in prothrombin complex concentrates. Blood Coagul Fibrinolysis 2004, 15:405-411.

30. Gallistl S, Cvirn G, Leschnik B, Muntean W: Respective roles of factors II, VII, $\mathrm{IX}$, and $\mathrm{X}$ in the procoagulant activity of FEIBA. Blood Coagul Fibrinolysis 2002, 13:653-655.

31. Tripodi A, Salerno F, Chantarangkul V, Clerici M, Cazzaniga M, Primignani M, Mannuccio Mannucci P: Evidence of normal thrombin generation in cirrhosis despite abnormal conventional coagulation tests. Hepatology 2005, 41:553-558.

32. Allen GA, Wolberg AS, Oliver JA, Hoffman M, Roberts HR, Monroe DM: Impact of procoagulant concentration on rate, peak and total thrombin generation in a model system. J Thromb Haemost 2004, 2:402-413.

33. Xi M, Beguin S, Hemker HC: The relative importance of the factors II, VII, IX and $X$ for the prothrombinase activity in plasma of orally anticoagulated patients. Thromb Haemost 1989, 62:788-791.

34. Dielis AW, Castoldi E, Spronk HM, van Oerle R, Hamulyak K, Ten Cate H, Rosing $\mathrm{J}$ : Coagulation factors and the protein $\mathrm{C}$ system as determinants of thrombin generation in a normal population. J Thromb Haemost 2008, 6:125-131.

35. Makris M, Watson HG: The management of coumarin-induced overanticoagulation annotation. Br J Haematol 2001, 114:271-280

36. Ostermann H, Haertel S, Knaub S, Kalina U, Jung K, Pabinger I: Pharmacokinetics of Beriplex $\mathrm{P} / \mathrm{N}$ prothrombin complex concentrate in healthy volunteers. Thromb Haemost 2007, 98:790-797.

37. Holland L, Warkentin TE, Refaai M, Crowther MA, Johnston MA, Sarode R: Suboptimal effect of a three-factor prothrombin complex concentrate (Profilnine-SD) in correcting supratherapeutic international normalized ratio due to warfarin overdose. Transfusion 2009, 49:1171-1177.

38. Ageno W, Garcia D, Aguilar MI, Douketis J, Finazzi G, Imberti D, lorio A, Key NS, Lim W, Marietta M, Prisco D, Sarode R, Testa S, Tosetto A, Crowther M: Prevention and treatment of bleeding complications in patients receiving vitamin K antagonists, part 2: treatment. Am J Hematol 2009, 84:584-588.

39. Kleinman S, Caulfield T, Chan P, Davenport R, McFarland J, McPhedran S, Meade M, Morrison D, Pinsent T, Robillard P, Slinger P: Toward an understanding of transfusion-related acute lung injury: statement of a consensus panel. Transfusion 2004, 44:1774-1789.
40. Siegenthaler MA, Schneider P, Vu DH, Tissot JD: Haemovigilance in a general university hospital: need for a more comprehensive classification and a codification of transfusion-related events. Vox Sang 2005, 88:22-30.

41. Alter HJ, Klein HG: The hazards of blood transfusion in historical perspective. Blood 2008, 112:2617-2626.

42. Stanworth SJ, Brunskill SJ, Hyde CJ, McClelland DB, Murphy MF: Is fresh frozen plasma clinically effective? A systematic review of randomized controlled trials. Br J Haematol 2004, 126:139-152

43. Chowdhury P, Saayman AG, Paulus U, Findlay GP, Collins PW: Efficacy of standard dose and $30 \mathrm{ml} / \mathrm{kg}$ fresh frozen plasma in correcting laboratory parameters of haemostasis in critically ill patients. Br J Haematol 2004, 125:69-73.

44. Cartmill M, Dolan G, Byrne JL, Byrne PO: Prothrombin complex concentrate for oral anticoagulant reversal in neurosurgical emergencies. $\mathrm{Br} J$ Neurosurg. 2000, 14:458-461.

45. Fredriksson K, Norrving B, Stromblad LG: Emergency reversal of anticoagulation after intracerebral hemorrhage. Stroke 1992, 23:972-977

46. Makris M, Greaves M, Phillips WS, Kitchen S, Rosendaal FR, Preston EF: Emergency oral anticoagulant reversal: the relative efficacy of infusions of fresh frozen plasma and clotting factor concentrate on correction of the coagulopathy. Thromb Haemost 1997, 77:477-480.

47. Huttner HB, Schellinger PD, Hartmann M, Kohrmann M, Juettler E, Wikner J, Mueller S, Meyding-Lamade U, Strobl R, Mansmann U, Schwab S, Steiner T: Hematoma growth and outcome in treated neurocritical care patients with intracerebral hemorrhage related to oral anticoagulant therapy: comparison of acute treatment strategies using vitamin $\mathrm{K}$, fresh frozen plasma, and prothrombin complex concentrates. Stroke 2006, 37:1465-1470

48. Sorensen B, Johansen P, Nielsen GL, Sorensen JC, Ingerslev J: Reversal of the International Normalized Ratio with recombinant activated factor VII in central nervous system bleeding during warfarin thromboprophylaxis: clinical and biochemical aspects. Blood Coagul Fibrinolysis 2003, 14:469-477.

49. Tripodi A, Primignani M, Chantarangkul V, Clerici M, Dell'Era A, Fabris F, Salerno F, Mannucci PM: Thrombin generation in patients with cirrhosis: the role of platelets. Hepatology 2006, 44:440-445.

50. Romisch J, Bonik K, Muller HG: Comparative in vitro investigation of prothrombin complex concentrates. Semin Thromb Hemost 1998, 24:175-181.

51. Mittermayr M, StreifW, Haas T, Fries D, Velik-Salchner C, Klingler A, Oswald E, Bach C, Schnapka-Koepf M, Innerhofer P: Hemostatic changes after crystalloid or colloid fluid administration during major orthopedic surgery: the role of fibrinogen administration. Anesth Analg 2007, 105:905-917.

52. Sorensen B, Ingerslev J: Tailoring haemostatic treatment to patient requirements - an update on monitoring haemostatic response using thrombelastography. Haemophilia 2005, 11(Suppl 1):1-6.

53. Rivard GE, Brummel-Ziedins KE, Mann KG, Fan L, Hofer A, Cohen E: Evaluation of the profile of thrombin generation during the process of whole blood clotting as assessed by thrombelastography. J Thromb Haemost 2005, 3:2039-2043

54. World Federation of Hemophilia Registry of Clotting Factor Concentrates [http://www.wfh.org/2/docs/Publications/Treatment_Products/ Monographs/FF6_Registry_8th_2008.pdf]

55. Pabinger I, Tiede A, Kalina U, Knaub S, Germann R, Ostermann H: Impact of infusion speed on the safety and effectiveness of prothrombin complex concentrate: a prospective clinical trial of emergency anticoagulation reversal. Ann Hematol 2010, 89:309-316.

doi:10.1186/cc9311

Cite this article as: Sørensen B, et al:: Clinical review: Prothrombin complex concentrates - evaluation of safety and thrombogenicity. Critical Care 2011, 15:201. 